\title{
UPAYA PENINGKATAN KOMPETENSI GURU AGAMA ISLAM DI MADRASAH ALIYAH SWASTA AL-WASHLIYAH 22 MEDAN TEMBUNG
}

\section{Oleh:}

\section{Nashran Azizan ${ }^{1}$}

\begin{abstract}
The competence becomes a purpose that must be achieved by a teacher based on standardization for developing profession ability so it gets on professional level. Being professional teacher must increase the competence in teacher. Therefore this research aims to describe it (pedagogic, personality, professional, and social ability) of religion teacher in Madrasah Aliyah Swasta (MAS) Al-Washliyah 22 Medan Tembung. This is field research using qualitative naturalistic method where researcher looks for and uses descriptive data such as words and opinion given by research subject. Data collection is conducted in interview and documentation method while analysis technique is conducted in data reduction, data presentation and conclusion. Data analysis is conducted while collecting data and after all data are collected or after the research is done in the field. This research shows that the effort that is done by religion teacher in MAS Al-Washliyah 22 Medan Tembung in improving their competence is good but there is still something needed such as teacher personality training and the use of computer science and technology training.
\end{abstract}

Keywords: Competence, Religion Teacher

\footnotetext{
${ }^{1}$ Dosen PGMI IAIN Padangsidimpuan, email: Nashran_azizah@yahoo.com
} 


\section{PENDAHULUAN}

Undang-undang No. 14 tahun 2005 tentang Guru dan Dosen pasal 1 ayat 10 yang di dalamnya berisi bahwa kompetensi merupakan seperangkat pengetahuan, keterampilan, dan sikap yang harus dimiliki, dihayati dan dijiwai oleh guru atau dosen dalam melaksanakan tugas profesi.

Guru adalah pendidik dengan tugas utama mendidik, mengajar, membimbing, mengarahkan, melatih, membentuk, dan mengevaluasi siswa. Guru yang berkompeten seyogianya memiliki kemampuan melaksanakan tugas utamanya sehingga dapat mewujudkan kinerja yang profesional. Pelaksanaan tugas utama guru tidak dapat dipisahkan dari kemampuan seorang guru dalam penguasaan dan implementasi kompetensinya, karena sangat menentukan tercapainya kualitas proses pembelajaran, bimbingan, dan pelaksanaan tugas tambahan yang relevan dengan harapan.

Peningkatan kompetensi guru dapat dilakukan dengan belajar mandiri (otodidak), kegiatan ilmiah (seminar dan lokakarya), program pendidikan dan latihan, dan program studi lanjut. Peningkatan kompetensi guru seyogianya menjadi program rutin bagi sekolah maupun Lembaga yang turut ikut andil untuk pengembangan pendidikan ${ }^{2}$.

Salah satu upaya untuk meningkatkan kompetensi guru adalah melalui kinerja profesi guru. Karena pada hakikatnya guru bukan hanya mengajar ataupun transfer ilmu saja, melainkan membimbing maupun mendidik dan membentuk sehingga terjadi meresapi tujuan dalam menjiwai tanggung jawab pendidik yang di dalamnya bertujuan untuk mencerdaskan anak bangsa yang Islami. Oleh sebab itu, upaya peningkatan kompetensi guru agama Islam dalam melaksanakan tugas pendidikan merupakan suatu kewajiban yang tidak dapat dihindari.

Fokus kajian pada penelitian ini adalah kompetensi guru agama Islam. Melirik kebelakang bahwa agama Islam adalah mata pelajaran inti disetiap jenjang pendidikan yang mana dapat memberikan kontribusi positif terhadap pencapaian tujuan pendidikan nasional. Kontribusi itu dapat terlaksana secara optimal apabila kegiatan pembelajaran dapat menciptakan suasana belajar yang inovatif, kreatif, dan mengasyikkan. Oleh karena itu, guru agama Islam yang berkompeten harus memiliki kemampuan pedagogik, kepribadian, profesional, dan sosial.

Berdasarkan Peraturan Menteri Pendidikan Nasional Republik Indonesia No. 16 tahun 2007 tentang Standar Kualifikasi Akademik dan Kompetensi Guru. Dijelaskan bahwa Standar Kompetensi Guru dikembangkan secara utuh dari 4 kompetensi utama,

\footnotetext{
${ }^{2}$ S. Syamsu, "Peningkatan Kompetensi Guru Pendidikan Agama Islam Berbasis Musyawarah Guru Mata Pelajaran Pada Sekolah Menengah Pertama di Kota Palopo Propinsi Sulawesi Selatan," Holistik: Journal For Islamic Social Sciences 2, no. 2 (2017), h. 3 , http://www.syekhnurjati.ac.id/jurnal/index.php/holistik.
}

Upaya Peningkatan 
yaitu: (1) kompetensi Pedagogik, (2) kompetensi profesional, (3) kompetensi kepribadian, (4) kompetensi sosial.

\section{Kompetensi Pedagogik}

Kompetensi pedagogic adalah kemampuan guru dengan pemahaman peserta didik dan pengelolaan pembelajaran yang mendidik dan dialogis ${ }^{3}$. Lebih lanjut, Mulyasa menyatakan bahwa kompetensi pedagogic merupakan kemampuan guru dalam pengelolaan pembelajaran peserta didik meliputi:
a. Pemahaman wawasan atau landasan pendidikan.
b. Pemahaman terhadap peserta didik.
c. Pengembangan kurikulum atau silabus.
d. Perencanaan pembelajaran.
e. Pelaksanaan pembelajaran yang mendidik dan dialogis.
f. Pemanfaatan teknologi pembelajaran.
g. Evaluasi Hasil Belajar (EHB).
h. Pengembangan peserta $\operatorname{didik}^{4}$.

\section{Kompetensi Kepribadian}

Undang-Undang Republik Indonesia No. 14 tahun 2005 tentang Guru dan Dosen pasal 10 ayat 1 dikemukakan bahwasanya yang dimaksud dengan kompetensi kepribadian adalah kemampuan kepribadian yang mantap, stabil, dewasa, arif, dan berwibawa, menjadi teladan bagi peserta didik, dan berakhlak mulia.

Dalam bukunya Uzer Usman mengemukakan bahwasanya guru yang memiliki kompetensi kepribadian baik antara lain:

1. Berkepribadian dan bertakwa kepada Tuhan Yang Maha Esa dan mengamalkan perilaku terpuji pada masyarakat sosial.

2. Berinteraksi dan berkomunikasi dengan baik dan terpuji.

3. Melaksanakan bimbingan dan penyuluhan terhadap peserta didik dengan arif dan bijaksana ${ }^{5}$.

\section{Kompetensi Profesional}

Undang-Undang Republik Indonesia No. 14 tahun 2005 tentang Guru dan Dosen pasal 10 ayat 1 dikemukakan bahwasanya yang dimaksud dengan kompetensi profesional adalah kemampuan penguasaan materi pembelajaran secara luas dan

\footnotetext{
${ }^{3}$ Trianto, Triwulan, and Tutik, Sertifikasi Guru dan Upaya Peningkatan Kualifikasi, Kompetensi, Dan Kesejahteraan (Jakarta: Prestasi Pustaka, 2007), h. 85. 75.

${ }^{4}$ E. Mulyasa, Standar Kompetensi dan Sertifikasi Guru (Bandung: Remaja Rosda Karya, 2007), h.

${ }^{5}$ Uzer Usman, Menjadi Guru Profesional (Bandung: Remaja Rosda Karya, 1990), h. 16.
}

Upaya Peningkatan Nashran 
mendalam yang memungkinkan membimbing peserta didik memenuhi standar kompetensi yang ditetapkan dalam Standar Nasional Pendidikan.

Guru professional adalah guru yang memiliki kompetensi secara penuh dan menjadikan pekerjaannya sebagai sumber penghasilan kehidupan. Profesionalisme seseorang guru adalah kondisi, arah, nilai, dan kualitas suatu keahlian dan kewenangan dalam bidang pendidikan dan pengajaran. Sementara guru yang profesional adalah guru yang memiliki kompetensi yang dinyatakan memiliki sikap dan pribadi, sosial ataupun akademis yang baik, dan menguasai materi ajar yang akan disampaikan ${ }^{6}$.

Adapun indicator kompetensi professional guru menurut $\mathrm{Madjid}^{7}$, yaitu:

a. Mampu menguasai materi, struktur, konsep, dan sudut pandang keilmuan yang sesuai dengan bidang studi yang diampu.

b. Mampu menguasai kompetensi inti dan kompetensi dasar dalam mata pelajaran yang diampu.

c. Mampu mengembangkan materi pelajaran yang diampu dengan kreatif dan menarik perhatian siswa.

d. Mampu mengembangkan keprofesionalan secara berkelanjutan dengan melakukan kegiatan reflektif diri.

e. Mampu memanfaatkan teknologi informasi dan komunikasi untuk mengembangkan diri dalam mengikuti zaman.

Selain itu, guru yang mempunyai kompetensi profesional adalah guru yang mempunyai ciri sebagai berikut:

a. Mengenal dan memaham itu juan pendidikan.

b. Menguasai bahan pengajaran.

c. Menyusun program pengajaran yang terdiri menetapkan tujuan pelajaran, memilih dan mengembangkan bahan pelajaran, mengembangkan strategi pembelajaran, mengembangkan media belajar, memanfaatkan sumber belajar.

d. Melaksanakan program pengajaran yang telah disusun.

e. Menilai hasil program pelajaran yang telah dilaksanakan.

\section{Kompetensi Sosial}

Kompetensi sosial juga telah dijabarkan dalam Undang-Undang Republik Indonesia No. 14 tahun 2005 tentang Guru dan Dosen pasal 10 ayat 1 dikemukakan bahwasanya yang dimaksud dengan kompetensi sosial adalah kemampuan guru dari

\footnotetext{
${ }^{6}$ Kunandar, Guru Profesional Implementasi Kurikulum Tingkat Satuan Pendidikan dan Persiapan Menghadapi Sertifikasi Guru (Jakarta: Raja Grafindo Persada, 2007), h. 46.

${ }^{7}$ Abdul Madjid, Pengembangan Kinerja Guru Melalui: Kompetensi, Komitmen dan Motivasi Kerja (Yogyakarta: Samudra Biru, 2016), h. 35.
} 
sebagian masyarakat untuk berkomunikasi dan bergaul secara efektif dengan peserta didik, tenaga kependidikan, orang tua atau wali peserta didik, dan masyarakat sekitar.

Kompetensi sosial merupakan kemampuan guru dari sebagian masyarakat yang sekurang-kurangnya memiliki kompetensi sebagai berikut:

a. Berkomunikasi secara lisan, tulisan, maupun isyarat.

Dalam interaksi belajar mengajar bermaksud menyampaikan informasi yang berupa pengetahuan dari guru kepada siswanya ataupun sebaliknya siswa juga menerima informasi tersebut dari guru baik secara lisan, tulisan, ataupun isyarat.

b. Menggunakan teknologi komunikasi dan informasi secara fungsional.

Kemajuan zaman saat ini juga menghantarkan sekolah dan dunia pendidikan untuk memahami dan mempelajari informasi dan teknologi, dengan adanya ini maka komunikasi guru dan siswa akan menjadi mudah dan semakin maju. Maka dari itu terlebih dahulu seorang guru mengaktifkan diri untuk memahami dan mempelajari dunia teknologi informasi tersebut.

c. Bergaul secara efektif dengan peserta didik, sesame pendidik, tenaga kependidikan, orang tua wali peserta didik.

d. Bergaul secara santun dengan masyarakat sekitar.

Seorang guru hendaklah bersikap cakap, terampil, lincah, dan mampu memberikan pengetahuan sesuai dengan perkembangan teknologi dan informasi, dengan tidak mengalahkan bergaul dengan masyarakat. Karena guru adalah makhluk sosial yang tidak lepas dari kehidupan masyarakat sosial dan lingkungan sekitar. Oleh karena itu, guru dituntut untuk memiliki kompetensi sosial yang memadai, terutama dalam kaitannya dengan pendidikan, yang tidak terbatas pada pendidikan di sekolah tetapi juga pada pendidikan yang terjadi dan berlangsung pada kehidupan masyarakat sosial.

Menurut Purwanto ${ }^{8}$ dalam rangka meningkatkan kompetensi, guru harus selalu berusaha untuk melakukan:

a. Memahami tuntutan standar profesi yang ada. Ini harus diprioritaskan karena: (a) persaingan global sekarang memungkinkan adanya mobilitas guru lintas negara. (b) seorang guru harus mengikuti tuntutan perkembangan profesi secara global, dan tuntutan masyarakat yang menghendaki pelayanan yang lebih baik. Cara satu-satunya untuk memenuhi standar profesi ini adalah dengan belajar secara terus menerus sepanjang hayat, dengan membuka diri yakni mau mendengarkan dan melihat perkembangan baru di bidangnya.

\footnotetext{
${ }^{8}$ Novaria Marissa, "Upaya Meningkatkan Kompetensi dan Profesionalisme Guru Pada Era Sertifikasi," Meretas 4, no. 2 (2017), h. 82, http://jurnal.upgriplk.ac.id/index.php/meretas/article/view/51.
}

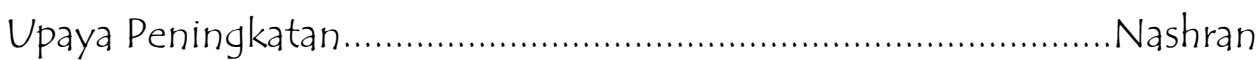


b. Mencapai kualifikasi dan kompetensi yang dipersyaratkan. Dipenuhinya kualifikasi dan kompetensi yang memadai, maka guru memiliki posisi tawar yang kuat dan memenuhi syarat yang dibutuhkan. Peningkatan kualitas dan kompetensi ini dapat ditempuh melalui inservice training.

c. Membangun hubungan yang baik dan luas, termasuk lewat organisasi. Upaya membangun hubungan yang baik dan luas dapat dilakukan guru dengan membina jaringan kerja (networking). Guru harus berusaha mengetahui apa yang telah dilakukan oleh temannya yang sukses. Melalui networking ini guru dapat memperoleh akses terhadap inovasi-inovasi untuk perkembangan pendidikan.

d. Mengembangkan etos kerja atau budaya kerja yang mengutamakan pelayanan bermutu tinggi. Artinya, guru harus memberikan pelayanan prima kepada siswa.

e. Mengadopsi inovasi atau mengembangkan kreativitas dalam pemanfaatan teknologi komunikasi dan informasi mutakhir agar senantiasa tidak ketinggalan zaman dalam mengelola pembelajaran. Berkembangnya zaman menuntut guru untuk tetap mampu memanfaatkan media dan ide-ide baru dalam bidang teknologi yang dikolaborasikan dengan pendidikan agar pembelajaran dapat berkembang sesuai zamannya.

Dari uraian di atas, maka kami memandang perlu untuk melakukan penelitian dengan judul "Upaya Peningkatan Kompetensi Guru Agama Islam MAS Al-Washliyah 22 Medan Tembung”. Penelitian ini bertujuan untuk mendeskripsikan hasil wawancara di lapangan kepada guru-guru terhadap kompetensi guru agama Islam. Hasil penelitian ini nantinya sangat diperlukan dalam rangka peningkatan kompetensi, yaitu pada segi pedagogik, kepribadian, profesional, dan sosial guru agama Islam.

\section{METODE PENELITIAN}

Penelitian ini merupakan penelitian lapangan (field research) yang menggunakan metode kualitatif naturalistik. Kualitatif naturalistic merupakan penelitian yang mengkaji data sehingga menggambarkan realitas sosial yang kompleks dan konkrit. Bogdan dan Taylor ${ }^{9}$ menyatakan bahwa penelitian memiliki prosedur yang menghasilkan data deskriptif tentang orang melalui tulisan dan kata-kata yang diucapkan dan perilaku yang dapat diamati. Artinya, penelitian kualitatif naturalistic adalah penelitian yang dilakukan dalam latar alamiah, dan lebih menekankan pada

\footnotetext{
9Salim and Syahrum, Metodologi Penelitian Kualitatif (Bandung: Cipustaka Media, 2007), h. 46.
}

Upaya Peningkatan ............................................................................. 
deskripsi data yang diperoleh melalui penelitian lapangan. Data yang diperoleh dalam penelitian ini menggunakan wawancara dan dokumentasi.

Adapun pendekatan penelitian yang digunakan dalam penelitian ini adalah interaktif, yaitu untuk mengetahui dan memahami upaya guru dalam peningkatan kompetensi guru agama Islam di Madrasah Aliyah Swasta Al-Washliyah 22 Medan Tembung. Penelitian ini menggunakan pendekatan keilmuan, yaitu pada kajian ilmu pendidikan. Penelitian ini dilaksanakan selama tiga bulan, yaitu bulan Januari sampai Maret tahun 2019.

Menurut Lofland ${ }^{10}$, sumber data utama dalam penelitian kualitatif adalah katakata dan tindakan, selebihya adalah data tambahan, seperti dokumen dan lain-lain. Maka dari itu, sumber data dalam penelitian ini didasarkan pada dua sumber, yaitu: (1) Sumber data primer, yaitu sumber pokok dalam penulisan yang diperoleh dari guru Madrasah Aliyah Swasta Al-Washliyah 22 Medan Tembung. (2) Sumber data skunder, yaitu sumber data pendukung/ pelengkap, dalam hal ini akan diperoleh dari guru Madrasah Aliyah Swasta Al-Washliyah 22 Medan Tembung dan dokumentasidokumentasi yang dapat mendukung penelitian.

Teknik pengumpulan data pada penelitian kualitatif menurut Lincoln dan Guba $^{11}$ ialah data diperoleh dengan menggunakan wawancara dan dokumentasi. Demikian halnya pada penelitian ini data diperoleh melalui: (1) Wawancara, melakukan wawancara dengan mengajukan sejumlah pertanyaan-pertanyaan yang berkaitan dengan penelitian, dan penelitian dilakukan secara terbuka, sehingga subjek penelitian mempunyai keluasan untuk menyatakan keinginan dan harapan mereka. Setelah pertanyaan-pertanyaan bersifat terbuka, kemudian dilanjutkan dengan memperdalam wawancara untuk menggali tentang kompetensi guru agama. Wawancara juga dilakukan terhadap kepala sekolah dan guru. (2) Dokumentasi, memoto kegiatan guru maupun siswa.

Kemudian, pengelolaan data dilakukan dengan cara: (1) Reduksi data, untuk memudahkan membuat kesimpulan terhadap data yang diperoleh selama pelaksanaan penelitian. Reduksi data dimulai dengan mengidentifikasikan semua catatan dan data lapangan yang memiliki makna yang berkaitan dengan fokus dan masalah penelitian harus disisihkan dari kumpulan data kemudian membuat kode pada setiap satuan supaya tetap dapat ditelusuri asalnya dan menyusun hipotesis (menjawab pertanyaan penelitian). (2) Penyajian data, sekumpulan informasi tersusun yang member kemungkinan adanya penarikan kesimpulan dan pengambilan tindakan. Data yang dianalisis disajikan dalam bentuk grafik, tabel, matriks, dan bagan guna menggabungkan informasi yang disusun dalam suatu bentuk padu sehingga dapat

${ }^{10}$ Moleong Lexy, Metode Penelitian Kualitatif (Remaja Rosdakarya, 2005), h. 324.

${ }^{11}$ Salim dan Syahrum, Metodologi Penelitian Kualitatif, h. 114.

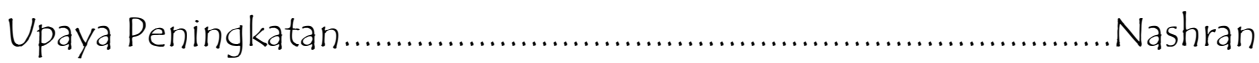


dengan mudah peneliti mengetahui apa yang terjadi untuk menarik kesimpulan. (3) Penarikan kesimpulan, setelah data terkumpul melalui wawancara dan dokumentasi, selanjutnya diproses dan dianalisis sehingga menjadi data yang siap disajikan yang akhirnya dapat ditarik menjadi kesimpulan hasil penelitian. Kesimpulan awal masih bersifat longgar, tetap terbuka dan belum jelas kemudian meningkat menjadi kesimpulan akhir seiring dengan bertambahnya data sehingga kesimpulan menjadi suatu konfigurasi yang utuh.

\section{HASIL DAN PEMBAHASAN}

\section{A. Kompetensi Pedagogik}

Berdasarkan hasil wawancara dengan Siti Fatimah selaku guru mata pelajaran Alquran Hadis diperoleh informasi bahwa upaya guru agama Islam terhadap kompetensi pedagogic dari aspek pemahaman peserta didik sudah mulai ditingkatkan. Menurutnya, upaya guru dalam memberikan pemahaman kepada siswa selama ini dengan melakukan evaluasi yang dilakukan setelah menyelesaikan materi pelajaran diakhir pertemuan.

Kemudian pada aspek perencanaan pembelajaran sudah mulai ditingkatkan. Menurutnya, seluruh pihak guru khususnya guru agama Islam sudah diberikan pembinaan atau pelatihan dalam penyusunan perencanaan pembelajaran guna meningkatkan kompetensi guru.

Pada aspek pengembangan peserta didik sudah mulai ditingkatkan. Menurutnya, upaya guru dan sekolah selama ini memberikan forum kepada siswa untuk meningkatkan jiwa religi dan selama ini membimbing siswa untuk mengembangkan ilmu keislaman dalam kegiatan KKD (Kursus Kader Dakwah).

Dari uraian hasil wawancara di atas dapat disimpulkan bahwa upaya guru agama Islam dalam meningkatkan kompetensi pedagogic sudah baik dan ada peningkatan. Namun ada sedikit yang perlu direvisi, yakni memberikan ketegasan dalam memberikan nilai kepada siswa, karena guru terlalu baik dalam memberikan nilai.

\section{B. Kompetensi Kepribadian}

Berdasarkan hasil wawancara dengan Rosmina Batubara selaku guru mata pelajaran Fikih diperoleh informasi bahwa upaya guru agama Islam terhadap kompetensi kepribadian dari aspek disiplin, arif, dan berwibawa sudah mulai ditingkatkan. Menurutnya, upaya menjadikan guru agama Islam untuk lebih, disiplin, arif dan berwibawa, selama ini membuka diri untuk selalu menjadi yang terbaik, dan 
menjaga diri agar selalu tepat waktu, dan janji, sudah dilakukan setiap harinya di sekolah.

Pada aspek berakhlak mulia, upaya guru agama Islam sudah baik. Menurutnya, upaya untuk meningkatkan kompetensi guru pengembangan pribadi masing-masing guru, dan selama ini yang terlihat pada keseharian guru agama Islam masih tetap memiliki akhlak. Misalnya dalam keadaan rapat keseluruhan guru, terlihat guru agama Islam masih pada koredar yang baik, artinya bahasa-bahasa yang dituturkan saat berbicara selalu menggunakan ungkapan-ungkapan yang baik dan enak didengar.

Dari uraian hasil wawancara di atas dapat disimpulkan bahwa upaya guru agama Islam dalam meningkatkan kompetensi kepribadian sudah baik dan ada peningkatan. Artinya guru agama Islam sangat layak dinyatakan berkompetensi.

\section{Kompetensi Profesional}

Berdasarkan hasil wawancara dengan Ngatminah selaku guru Akidah Akhlak diperoleh informasi upaya guru agama Islam terhadap kompetensi profesional. Menurutnya, selama ini upaya yang dilakukan guru dalam penguasaan materi mau pun menyiapkan perangkat pembelajaran sudah ada upaya peningkatan.

Dari uraian hasil wawancara di atas dapat disimpulkan bahwa upaya guru agama Islam dalam meningkatkan kompetensi kepribadian sudah baik dan ada peningkatan. Namun, perlu ditingkatkan lagi dari segi kekonsistensian antara perangkat pembelajaran dengan yang disampaikan kepada siswa agar pembelajaran menjadi efektif dan efisien.

\section{Kompetensi Sosial}

Berdasarkan hasil wawancara dengan Rajab Munthe selaku guru Sejarah Kebudayaan Islam diperoleh informasi bahwa upaya meningkatkan kompetensi guru agama Islam dalam menyikapi kemampuan berkomunikasi secara lisan, tulisan, dan isyarat yang menunjukkan dalam meningkatkan berkomunikasi, guru sudah terbiasa mengucap salam atau bertegur sapa ketika bertemu dengan guru dan siswa.

Selain itu komunikasi antar guru dan siswa dibiasakan untuk menggunakan teknologi berupa media whatsapp (WA), telepon, telegram, facebook, dan email. Biasanya komunikasi yang biasa digunakan ialah melalui sms dan WA. Ini biasanya dilakukan jika siswa meminta izin tidak masuk kelas ataupun ada yang perlu didiskusikan terkait pelajaran. Itupun terkadang masih ada guru yang belum pandai menggunakan WA, dan yang sering digunakan hanya melalui telepon. Sedangkan media youtube ada juga guru yang menggunakannya, tetapi hanya beberapa guru saja, itu pun masih perlu latihan agar lihai menggunakannya sehingga bisa menunjang pembelajaran. 
Untuk pelajaran Alquran hanya masih sebatas penggunaan media visual dari murottal Alquran 30 juz saja belum merambah pada media internet atau komputer.

Dari uraian hasil wawancara di atas dapat disimpulkan bahwa upaya guru agama Islam dalam meningkatkan kompetensi sosial upaya yang dilakukan selama ini adalah pihak sekolah sudah menyediakan fasilitas internet, dan laboratorium komputer. Kemudian upaya guru agama Islam masih beberapa guru yang mengembangkan kemampuannya dengan selalu membiasakan diri untuk menggunakan media internet tersebut. Maka perlu dibenahi agar pihak guru agama Islam terus melatih diri dan pihak sekolah juga selalu mendorong dengan member motivasi kepada guru-guru agar selalu berinovasi untuk pengembangan pembelajaran agama Islam di MAS Al-Washliyah 22 Medan Tembung.

\section{PENUTUP}

Perolehan yang ditemukan pada penelitian ini bahwa upaya yang dilakukan guru agama Islam dan kepala sekolah dalam meningkatkan kompetensinya sebagai berikut: (1) Kompetensi pedagogik para guru agama di MAS Al-Washliyah 22 Medan Tembung selalu mengadakan pelatihan, diklat, workshop, dan MGMP (Musyawarah Guru Mata Pelajaran) dengan tujuan untuk memperkuat keprofesian guru dan juga didukung pihak sekolah; (2) Kompetensi kepribadian lebih menekankan pada pengembangan kepribadian diri sendiri dan penerapan sikap kepada siswa, dan selama ini sekolah belum pernah mengadakan pelatihan kepribadian guru; (3) Kompetensi profesional, sekolah selalu memberikan pelatihan dan diklat bagi setiap guru untuk meningkatkan keprofesionalitasannya, dan melakukan evaluasi keprofesionalan guru setiap tahunnya; (4) Kompetensisosial guru agama Islam selama ini menerapkan pada diri sendiri setiap guru untuk bersikap sosial dengan perilaku sopan santun. Kemudian untuk pengembangan dunia informasi dan teknologi masih ada beberapa guru agama Islam yang belum menguasai dan terbiasa menggunakannya dikarenakan faktor usia yang sudah tidak memungkinkan untuk mempelajarinya karena sudah sepuh (tua dalam bahasa Indonesia). 


\section{DAFTAR PUSTAKA}

Kunandar. Guru Profesional Implementasi Kurikulum Tingkat Satuan Pendidikan dan Persiapan Menghadapi Sertifikasi Guru. Jakarta: Raja Grafindo Persada, 2007.

Lexy, Moleong. Metode Penelitian Kualitatif. Remaja Rosdakarya, 2005.

Madjid, Abdul. Pengembangan Kinerja Guru Melalui: Kompetensi, Komitmen dan Motivasi Kerja. Yogyakarta: Samudra Biru, 2016.

Marissa, Novaria. "Upaya Meningkatkan Kompetensi dan Profesionalisme Guru Pada Era Sertifikasi." Meretas 4, no. 2 (2017): 78-86. http://jurnal.upgriplk.ac.id/index.php/meretas/article/view/51.

Mulyasa, E. Standar Kompetensi dan Sertifikasi Guru. Bandung: Remaja Rosda Karya, 2007.

Salim, and Syahrum. Metodologi Penelitian Kualitatif. Bandung: Cipustaka Media, 2007.

Syamsu, S. "Peningkatan Kompetensi Guru Pendidikan Agama Islam Berbasis Musyawarah Guru Mata Pelajaran Pada Sekolah Menengah Pertama di Kota Palopo Propinsi Sulawesi Selatan." Holistik: Journal For Islamic Social Sciences 2, no. 2 (2017): 1-9. http://www.syekhnurjati.ac.id/jurnal/index.php/holistik.

Trianto, Triwulan, and Tutik. Sertifikasi Guru dan Upaya Peningkatan Kualifikasi, Kompetensi, dan Kesejahteraan. Jakarta: Prestasi Pustaka, 2007.

Usman, Uzer. Menjadi Guru Profesional. Bandung: Remaja Rosda Karya, 1990. 